Sri Florina

Laurence Zagoto ${ }^{1}$

\section{EFIKASI DIRI DALAM PROSES PEMBELAJARAN}

\begin{abstract}
Abstrak
Efikasi diri merupakan keyakinan atau kepercayaan individu mengenai kemampuan dirinya untuk mengorganisasi, melakukan suatu tugas, mencapai suatu tujuan, menghasilkan sesuatu dan mengimplementasi tindakan untuk menampilkan kecakapan-kecakapan tertentu. Proses psikologis efikasi diri dalam mempengaruhi fungsi manusia, melalui empat proses, yaitu: (1) Proses kognitif; (2) Proses motivasi; (3) Proses afeksi; dan (4) Proses Seleksi. Perkembangan efikasi diri siswa dipengaruhi oleh berbagai hal, salah satunya adalah peran guru. Guru dapat meyakini siswa akan kemampuan yang dimilikinya sehingga siswa memiliki kepercayaan diri selama proses pembelajaran. Pendekatan yang dilakukan guru dalam meningkatkan efikasi diri siswa bertujuan menghasilkan siswa yang dapat memperbaiki diri dan merefleksikan diri atas kelemahan diri dalam proses pembelajaran selama ini
\end{abstract}

Kata kunci: Efikasi Diri, Proses Pembelajaran

\begin{abstract}
Self-efficacy is an individual's beliefs or beliefs about his ability to organize, do a task, achieve a goal, produce something and implement actions to show certain skills. Psychological processes of self-efficacy in influencing human function, through four processes, namely: (1) cognitive processes; (2) The process of motivation; (3) affection process; and (4) Selection Process. The development of student self-efficacy is influenced by various things, one of which is the role of the teacher. The teacher can trust students of their abilities so that students have confidence during the learning process. The approach taken by the teacher in improving student self-efficacy aims to produce students who can improve themselves and reflect on their own weaknesses in the learning process so far.
\end{abstract}

Keywords: Self-Efficacy, Learning Process

\footnotetext{
${ }^{1}$ Dosen Prodi Bimbingan dan Konseling, STKIP Nias Selatan

Alamat email: zagoto.sflorence @gmail.com
} 


\section{PENDAHULUAN}

Pendidikan bagi kehidupan manusia merupakan kebutuhan mutlak yang harus dipenuhi sepanjang hayat agar kelompok manusia dapat hidup berkembang, maju, dan sejahtera. Pendidikan merupakan suatu keharusan bagi manusia dan berlangsung sepanjang hayat. Sejak kelahirannya ke dunia, anak memiliki kebutuhan untuk memperoleh pendidikan. Pendidikan sangat dibutuhkan oleh setiap manusia agar berakhlak mulia, memiliki watak yang baik, dan dapat melakukan aktivitas sosial di dalam masyarakat tempat mereka berada.

Siswa sebagai makhluk yang belum dewasa harus ditolong, dibantu, dibimbing, dilatih, serta diarahkan agar dapat mengembangkan potensinya secara optimal terutama dalam meningkatkan efikasi dirinya. Salah satu upaya yang dapat dilakukan adalah melalui pendidikan formal di sekolah. Hal ini sesuai dengan tujuan pendidikan nasional yang bertujuan untuk berkembangnya potensi peserta didik agar menjadi manusia yang beriman dan bertaqwa kepada Tuhan Yang Maha Esa, berakhlak mulia, sehat, berilmu, cakap, kreatif, mandiri, dan menjadi warga negara yang demokratis, serta bertanggung jawab.

Pelaksanaan pendidikan dapat menunjang keberhasilan bangsa dan negara dalam berbagai bidang kehidupan manusia. Pada umumnya, pelaksanaan pendidikan berada pada suatu proses yang berkesinambungan dalam setiap jenis dan jenjang pendidikan, dimana semuanya berkaitan pada suatu sistem pendidikan yang integral. Keberhasilan pendidikan dalam proses pembelajaran tergantung pada kemampuan guru mengolah pembelajaran yang dapat menciptakan situasi yang memungkinkan siswa belajar. Rendahnya mutu pendidikan disebabkan oleh kurang efektifnya proses pembelajaran. Penyebabnya dapat berasal dari siswa, guru, maupun sarana dan prasarana yang kurang memadai, minat, motivasi siswa yang rendah, serta kurangnya kemampuan siswa dalam belajar akan menyebabkan pembelajaran kurang efektif.

Peningkatan kemampuan siswa dalam belajar dapat dilakukan melalui bimbingan konseling baik secara individu maupun kelompok. Kegiatan membimbing sangat menentukan arah perkembangan siswa di sekolah, baik perkembangan pada prestasi akademik maupun non-akademik, serta perilaku-perilaku sosial lainnya. Hal-hal tersebut tentu terjadi dalam kegiatan pendidikan yang direalisasikan melalui kegiatan pembelajaran dan bimbingan. Kegiatan mengajar dan membimbing merupakan kegiatan yang terpadu dengan harapan agar siswa dapat belajar secara optimal dengan tujuan meningkatkan efikasi diri.

"Efikasi diri memberi ketahanan dan kekuatan bagi siswa dalam menghadapi situasi sulit di sekolah, sikap yang tidak lekas bosan, pantang menyerah dan tidak lamalama menyelesaikan suatu masalah dan tugas di sekolah merupakan ciri siswa yang memiliki efikasi diri yang tinggi. Siswa yang berefikasi diri tinggi dipercayai mampu dan sanggup menguasai berbagai tugas pelajaran yang diberikan, dan mampu meregulasi cara belajar mereka sendiri sehingga kesuksesan di dalam bidang akademik sangat mungkin untuk dapat dicapai" (Schunk dan Pajares, 2005:343). Dengan adanya efikasi diri pada siswa, maka akan membantu seseorang dalam menentukan pilihan dan 
usaha untuk maju, kegigihan dan ketekunan yang ditunjukkan dalam menghadapi kesulitan, dan derajat kecemasan atau tingkat ketenangan yang dialami saat individu mempertahankan tugas-tugas dalam kehidupan seseorang.

\section{PEMBAHASAN}

\section{a. Pengertian Efikasi Diri}

Efikasi diri bukan merupakan ekspektasi dari hasil tindakan kita. Efikasi merujuk pada keyakinan diri seseorang bahwa orang tersebut memiliki kemampuan untuk melakukan suatu perilaku, sementara ekspetasi atas hasil merujuk pada prediksi dari kemungkinan mengenai konsekuensi perilaku tersebut. Efikasi diri berbeda dengan konsep diri. Konsep diri mengacu pada persepsi-persepsi diri kolektif seseorang yang dibentuk melalui penglaman-pengalaman dengan lingkungan dan interprestasi terhadap lingkungan. Konsep diri tergantung pada penguatan-penguatan dan evaluasi-evaluasi oleh orang-orang lain yang penting bagi mereka.

Bandura dalam Sufirmansyah, (2015:140) menyatakan bahwa "efikasi diri merujuk kepada keyakinan pada kemampuan untuk mengatur dan melakukan tindakan yang diperlukan untuk mengelola situasi yang akan dihadapi”. Efikasi diri merupakan salah satu aspek pengetahuan tentang diri yang paling berpengaruh dalam kehidupan manusia seharihari. Hal ini disebabkan efikasi diri yang dimiliki ikut memengaruhi individu dalam menentukan tindakan yang akan dilakukan untuk mencapai suatu tujuan termasuk di dalamnya perkiraan berbagai kejadian yang akan dihadapi.

Efikasi diri tidak berkaitan dengan kecakapan yang dimiliki, tapi berkaitan dengan keyakinan individu mengenai hal apa yang dapat dilakukan dengan kecakapan yang ia miliki seberapa pun besarnya. Efikasi diri menekankan pada komponen keyakinan diri yang dimiliki seseorang dalam menghadapi situasi yang akan datang yang mengandung kekaburan, tidak dapat diramalkan, dan sering penuh dengan tekanan. Meskipun efikasi diri memiliki suatu pengaruh sebab yang besar pada tindakan kita, efikasi diri berkombinasi dengan lingkungan, perilaku sebelumnya, dan variabel-variabel personal lainnya, terutama harapan terhadap hasil untuk menghasilkan perilaku. Efikasi diri akan mempengaruhi beberapa aspek dari kognisi dan perilaku seseorang.

Efikasi diri sebagai perasaan kita terhadap kecukupan, efisiensi, dan kemampuan kita dalam mengatasi kehidupan. Santrock dalam Novariandhini dan Latifah, (2012:139) menyatakan "efikasi diri merupakan keyakinan dan kepercayaan seorang individu akan kemampuannya dalam mengontrol hasil dari usaha yang telah dilakukan". Efikasi diri dapat membawa pada perilaku yang berbeda di antara individu dengan kemampuan yang sama karna efikasi diri memengaruhi pilihan, tujuan, pengatasan masalah, dan kegigihan dalam berusaha.

Seseorang dengan efikasi diri percaya bahwa mereka mampu melakukan sesuatu untuk mengubah kejadian-kejadian di sekitarnya, sedangkan seseorang dengan efikasi diri rendah menganggap dirinya pada dasarnya tidak mampu mengerjakan segala sesuatu yang ada disekitarnya. Dalam situasi yang sulit, orang dengan efikasi yang rendah cenderung mudah menyerah. Sementara orang dengan efikasi diri yang tinggi akan berusaha lebih keras untuk mengatasi tantangan yang ada. Perasaan efikasi diri memainkan satu peran penting dalam mengatasi memotivasi pekerja untuk menyelesaikan pekerjaan yang menantang dalam kaitannya dengan pencapaian tujuan tertentu. 
Menurut Bandura dalam Widaryati, (2013:96) bahwa "efikasi diri merupakan keyakinan yang dipegang seseorang tentang kemampuannya dan juga hasil yang akan diperoleh dari kerja kerasnya yang akan mempengaruhi cara individu berperilaku". Efikasi diri pada dasarnya adalah hasil proses kognitif berupa keputusan, keyakinan, atau penghargaan tentang sejauh mana individu memperkirakan kemampuan dirinya dalam melaksanakan tugas atau tindakan tertentu yang diperlukan untuk mencapai hasil yang diinginkan (Zagoto, dkk., 2018; Sarumaha, 2018; Dakhi, O., 2013).

Dalam kehidupan sehari-hari, efikasi diri memimpin kita untuk menentukan cita-cita yang menantang dan tetap bertahan dalam menghadapi kesulitan-kesulitan. Ketika masalahmasalah muncul, perasaan efikasi diri yang kuat mendorong para siswa untuk tetap tenang dan mencari solusi daripada merenung ketidakmampuannya. Usaha dan kegigihan tersebut menghasilkan prestasi. Efikasi diri ini adalah indikator positif untuk melakukan evaluasi diri yang berguna untuk mengenal dan memahami diri serta kemampuan yang dimiliki diri sendiri.

Berdasarkan pendapat para ahli tersebut, maka dapat disimpulkan bahwa efikasi diri merupakan keyakinan atau kepercayaan individu mengenai kemampuan dirinya untuk mengorganisasi, melakukan suatu tugas, mencapai suatu tujuan, menghasilkan sesuatu dan mengimplementasi tindakan untuk menampilkan kecakapan-kecakapan tertentu.

\section{b. Proses-proses Efikasi Diri}

Bandura dalam Feist, (2011:136) menguraikan proses psikologis efikasi diri dalam mempengaruhi fungsi manusia. Proses tersebut dapat dijelaskan melalui cara-cara berikut:

1) Proses kognitif

Peserta didik dalam melakukan tugas akademiknya, peserta didik menetapkan tujuan dan sasaran perilaku sehingga peserta didik dapat merumuskan tindakan yang tepat untuk mencapai tujuan tersebut. Penetapan sasaran pribadi tersebut dipengaruhi oleh penilaian peserta didik akan kemampuan kognitifnya. Fungsi kognitif memungkinkan peserta didik untuk memprediksi kejadian-kejadian sehari-hari yang akan berakibat pada masa depan.

2) Proses motivasi

Motivasi peserta didik timbul melalui pemikiran optimis dari dalam dirinya untuk mewujudkan tujuan yang diharapkan. Individu berusaha memotivasi diri dengan menetapkan keyakinan pada tindakan yang akan dilakukan, merencanakan tindakan yang akan direalisasikan. Efikasi diri mempengaruhi atribusi penyebab, dimana individu yang memiliki efikasi diri akademik yang tinggi menilai kegagalannya dalam mengerjakan tugas akademik disebabkan oleh kurangnya usaha, sedangkan peserta didik dengan efikasi diri yang rendah menilai kegagalannya disebabkan oleh kurangnya kemampuan.

3) Proses afeksi

Afeksi terjadi secara alami dalam diri individu dan berperan dalam menentukan intensitas pengalaman emosional. Afeksi ditujukan dengan mengontrol kecemasan dan perasaan depresif yang menghalangi pola-pola pikir yang benar untuk mencapai tujuan. Kepercayaan individu terhadap kemampuannya mempengaruhi tingkat stres dan depresi yang dialami ketika menghadapi tugas yang sulit atau bersifat mengancam. Individu yang yakin dengan dirinya maka akan mampu mengontrol ancaman yang muncul dan tidak akan membangkitkan pola pikir yang mengganggu.

4) Proses seleksi 
Proses seleksi berkaitan dengan kemampuan peserta didik untuk menyeleksi tingkah laku dan lingkungan yang tepat, sehingga dapat mencapai tujuan yang diharapkan. Ketidakmampuan peserta didik dalam melakukan seleksi tingkah laku, maka akan membuat individu atau dalam hal ini siswa menjadi tidak percaya diri, bingung, dan mudah menyerah ketika menghadapi masalah atau situasi sulit. Efikasi diri dapat membentuk hidup peserta didik melalui pemilihan tipe aktivitas dan lingkungan. Dengan demikian, maka dapat melakukan seleksi tingkah laku yang harus dibuatnya.

Berdasarkan dari uraian tersebut, maka dapat disimpulkan bahwa proses efikasi diri meliputi proses kognitif, proses motivasi, proses afeksi, dan proses seleksi.

\section{c. Hal-hal yang Mempengaruhi Efikasi Diri}

Menurut Bandura dalam sechutack (2008:272) menyatakan bahwa efikasi diri memiliki dampak yang penting terhadap keberhasilan seseorang. Efikasi diri tergantung dari empat macam pengalaman, yaitu :

1. Pengalaman tentang penguasaan (keberhasilan sebelumnya)

Pengalaman keberhasilan pada tugas sebelumnya yang menunjukkan kemampuan dalam melakukan tugas tersebut secara kompeten.

2. Melihat orang lain berhasil mengerjakan suatu tugas (pemodelan sosial).

Melihat orang lain berhasil mengerjakan suatu tugas sehingga meningkatkan persepsi bahwa tugas tersebut dapat dikerjakan.

3. Dorongan dari orang lain (persuasi sosial)

Dorongan dari orang lain yang menyemangati kita dengan mengatakan bahwa mampu mengerjakan tugas tersebut.

4. Kondisi emosi

Foktor-foktor ini mempengaruhi persepsi individu tentang kemampuan untuk mencapai tujuan.

\section{d. Dimensi Efikasi Diri}

Menurut Bandura dalam Anggara, Yusuf dan Marjohan, (2016:43) bahwa efikasi diri memiliki tiga dimensi, adalah sebagai berikut:

1. Level

Level berkaitan dengan tingkatan kesulitan dari suatu ujian/tugas.

2. Kekuatan

Kekuatan berkaitan dengan bagaimana seseorang dapat menghadapi suatu tugas yang spesifik menunjukkan keyakinan atas kemampuannya untuk bertahan dalam usahanya, tidak mudah goyah, mampu bertahan lebih lama dalam usahanya mencapai target yang diinginkan.

3. Generalisasi

Generalisasi suatu penilaian terhadap seseorang untuk berbagai ujian/tugas yang berbeda dalam aktivitas dan situasi.

\section{SIMPULAN}

Efikasi diri pada siswa membantu mereka dalam menentukan pilihan dan usaha untuk maju, memperoleh kegigihan dan ketekunan yang ditunjukkan melalui usahanya mencapai target, serta mampu mengelola tingkat kecemasan yang lebih baik pada saat menghadapi kesulitan. Perkembangan efikasi diri siswa dipengaruhi oleh berbagai hal, salah satunya adalah 
peran guru. Guru dapat meyakini siswa akan kemampuan yang dimilikinya sehingga siswa memiliki kepercayaan diri selama proses pembelajaran. Pendekatan yang dilakukan guru dalam meningkatkan efikasi diri siswa bertujuan menghasilkan siswa yang dapat memperbaiki diri dan merefleksikan diri atas kelemahan diri dalam proses pembelajaran selama ini.

\section{DAFTAR PUSTAKA}

Feist. 2011. Theories Of Personality. Yogyakarta: Pustaka Pelajar.

Schustack, 2008. Kepribadian Teori Klasik dan Riset Modern. Jakarta: Erlangga.

Anggara, Fery, Yusuf, Muri, A. dan Marjohan, 2016. Efektivitas Layanan Bimbingan Kelompok dengan Modeling dalam Meningkatkan Efikasi Diri Siswa dalam Menghadapi Ujian. Konselor, 5 (1): 43.

Dakhi, O. "Aplikasi Pendeteksian Kerusakan File Akibat Virus Dengan Menggunakan Metode Heuristic." Pelita Informatika Budi Darma, vol. 4, no. 1, pp. 35-41, 2013.

Dakhi, O. 2013. Belajar Javascript Dengan Mudah Dan Detail. Jakarta: Dapur Buku. pp. 1-202.

Novariandhini, Ayu, D. dan Latifah, Melly. 2012. Harga Diri, Efikasi Diri, Motivasi Belajar dan Prestasi Akademik Siswa SMA pada Berbagai Model Pembelajaran. Jur. Ilm. Kel. \& Kons, 5 (2): 139.

Sarumaha, R., Harefa, D., \& Zagoto, Maria M. (2018). Upaya Meningkatkan Kemampuan Pemahaman Konsep Geometri Transformasi Refleksi Siswa Kelas XII-IPA-B SMA Kampus Telukdalam Melalui Model Pembelajaran Discovery Learning Berbantuan Media Kertas Milimeter. Jurnal Education and development, Vol.6 No.1, 90-96. https://doi.org/10.37081/ed.v6i1.668

Sufirmansyah. 2015. Pengaruh Efikasi Diri Terhadap Prestasi Belajar Mahasiswa Pascasarjana Prodi PAI STAIN Kediri dengan Motivasi sebagai Variabel Intervening. Didaktika Religia, 3 (2): 141.

Schunk, D. \& Frank Pajares. 2005. Development of Academic Self-Efficacy. San Diego: Academic Press.

Widaryati, Sri. 2013. Efektivitas Pengaruh Konseling Kelompok Terhadap Efikasi Diri Siswa. Psikopedagogia Jurnal Bimbingan dan Konseling, 2 (2): 96.

Zagoto, Maria M., Yarni, Nevi; Dakhi, O. (2019). Perbedaan Individu dari Gaya Belajarnya Serta Implikasinya Dalam Pembelajaran. Jurnal Review Pendidikan dan Pengajaran, 2(2), 259265.

Zagoto, Maria M. \& Dakhi, O (2018). Pengembangan Perangkat Pembelajaran Matematika Peminatan Berbasis Pendekatan Saintifik Untuk Siswa Kelas XI Sekolah Menengah Atas. Jurnal Review Pendidikan dan Pengajaran, 1(1), 157-170.

Zagoto, Maria M. (2018). Pengembangan Perangkat Pembelajaran Matematika Berbasis Realistic Mathematic Educations Untuk Siswa Kelas V Sekolah Dasar, Jurnal Education And Development, vol. 3, no. 1, p. 53, Feb. 2018. https://doi.org/10.37081/ed.v3i1.139 